\title{
Pertanggungjawaban Notaris Werda Atas Akta Yang Pernah Dibuat Dalam Masa Jabatannya
}

\author{
Nala Aprilia Damayanti \\ Fakultas Hukum Universitas Islam Indonesia Yogyakarta Indonesia \\ Jln. Cik Di Tiro No. 1, Yogyakarta, Indonesia 55223 \\ naladamayanti04@gmail.com
}

\begin{abstract}
This research examines how the retired public Notary is responsible for the deeds made during their term of office and how is the legal protection of the retired public Notary. This is a normative legal research with qualitative descriptive analysis. The method used is normative juridical. The result of the research shows that the Notary will still be responsible for the deed made whether the Notary is still in office or has retired. Legal protection for the retired public Notary if there is a problem with the deed that has been made includes the protection of the criminal law as referred to in Article 78 paragraph (1) number 3 of the Criminal Code, as well as in carrying out his position, the Notary must fulfill the obligations as stipulated in Article 16 paragraph (1) of UUJN. Legal protection is provided if the deed has fulfilled the elements of clarity, truth, completeness and legality.
\end{abstract}

Key Words: Accountability; legal protection; retired notary

\begin{abstract}
Abstrak
Penelitian ini mengkaji bagaimana pertanggungjawaban Notaris werda terhadap akta yang dibuat dalam masa jabatannya dan bagaimana pula perlindungan hukum terhadap Notaris werda tersebut. Penelitian hukum ini bersifat normatif dengan spesifikasi penelitian deskriptif analitis. Metode pendekatan yang digunakan yaitu yuridis normatif, dengan analisis deskriptif kualitatif. Hasil penelitian menyimpulkan bahwa Notaris akan bertanggungjawab atas akta yang dibuat selama Notaris masih menjabat maupun sudah werda. Perlindungan hukum terhadap Notaris werda apabila terjadi masalah dengan akta yang telah dibuat meliputi perlindungan hukum pidana yang mengacu pada Pasal 78 ayat (1) angka 3 KUHP, serta dalam menjalankan jabatannya, Notaris harus memenuhi kewajiban sebagaimana tertuang dalam Pasal 16 ayat (1) UUJN. Perlindungan hukum diberikan apabila pembuatan akta telah memenuhi unsur kejelasan, unsur kebenaran, unsur kelengkapan dan unsur keabsahan.
\end{abstract}

Kata-kata Kunci : Notaris werda; perlindungan hukum; pertanggungjawaban 


\section{Pendahuluan}

Masa jabatan Notaris sebagaimana diatur dalam Undang-Undang No. 30 Tahun 2004, disebutkan bahwa Notaris berhenti atau diberhentikan dari jabatannya dengan hormat apabila notaris tersebut telah berumur 65 tahun. Apabila Notaris mengajukan perpanjangan maka hanya untuk masa jabatan selama 2 tahun. Berakhirnya masa jabatan seorang notaris tidak mengakhiri tanggung jawab notaris terhadap akta yang dibuatnya. Meskipun Notaris telah werda namun apabila ada masalah yang berkaitan dengan akta yang dibuatnya, maka harus dapat dipertanggungjawabkan secara perdata.

M. Yahya Harahap mengemukakan, bahwa pada umumnya di dalam lalu lintas hukum perdata yang dimaksud dengan akta adalah suatu surat yang dibuat oleh Pejabat Umum (Notaris), dipergunakan sebagai pernyataan dari suatu perbuatan hukum dan dipergunakan sebagai alat pembuktian. ${ }^{1}$ Akta notaris sebagai akta otentik dibuat menurut bentuk dan tata cara yang ditetapkan dalam Pasal 38 s/d Pasal 65 Undang-Undang Nomor 2 Tahun 2014 tentang Jabatan Notaris. ${ }^{2}$ Suatu akta menjadi otentik jika memenuhi syarat yang telah ditentukan undang-undang, oleh karena itu seorang notaris dalam melaksanakan tugasnya tersebut wajib : .... melaksanakan dengan penuh disiplin, profesional dan integritas moralnya tidak boleh diragukan. Apa yang tertuang dalam awal dan akhir akta yang menjadi tanggungjawab notaris adalah ungkapan yang mencerminkan keadaan yang sebenar-benarnya pada saat pembuatan akta. ${ }^{3}$

Keberadaan lembaga notaris dilandasi kebutuhan akan suatu alat bukti yang mengikat selain alat bukti saksi. Pertanyaan dari mana asalnya notaris dahulu, hingga sekarang belum dapat terjawab. 4 Lembaga notaris yang merupakan lembaga independent, maka seorang notaris harus mampu menjalankan tugasnya secara netral, obyektif dan transparan. Setiap kegiatan notaris dalam memenuhi permintaan klien, tentunya harus dapat dipertanggung jawabkan secara hukum, baik pada saat pelaksanaan kegiatan maupun waktu dimasa yang akan datang.

Realitas dalam praktiknya, Notaris sering didudukan sebagai tergugat oleh pihak lainnya, yang mana merasa bahwa tindakan hukum yang dilakukannya tersebut dikategorikan sebagai tindakan atau perbuatan melawan hukum bersama-sama dengan para pihak yang juga terlibat dalam akta tersebut. Kondisi ini tentuya menjadi suatu persoalan yang harus diatasi dan perlunya perlindungan hukum terhap Notaris yang sudah tidak menjabat.

\footnotetext{
${ }^{1}$ M.Yahya Harahap, Hukum Acara Perdata tentang Gugatan, Persidangan, Penyitaan, Pembuktian dan Putusan Pengadilan, Sinar Grafika, Jakarta, 2004, hlm. 564.

2 Ibid., hlm. 16.

3 Tan Thong Kie, Studi Notariat-Serba Serbi Praktek Notaris, Ichtiar Baru Van Hoeve, Jakarta, 2000, hlm. 166.

${ }^{4}$ G. H. S. Lumban Tobing, Peraturan Jabatan Notaris, Erlangga, Jakarta, 1983, hlm. 4
} 
Perlindungan hukum terhadap notaris yang werda, merupakan bentuk upaya dalam menjaga integritas notaris. Notaris dalam pembuatan akta tentunya sudah melalui mekanisme yang standar dan dengan ketelitian yang tinggi. Namun demikian, seiring dengan berjalannya waktu, tidak menutup kemungkinan timbul gugatan terhadap akta diterbitkan oleh Notaris yang sudah purna bakti. Secara faktual, gugatan yang timbul tentunya menjadi tanggung jawab Notaris pengganti. Berkaitan dengan pembuatan akta, tentunya Notaris yang werda tidak terlepas dalam proses penyelesaian gugatan. Kondisi ini memberikan makna bahwa Notaris yang werda menjadi sumber utama dalam proses penyelesaian masalah sehingga perlunya perlindungan bagi Notaris yang werda. Perlindungan ini merupakan hak setiap manusia sebagaimana termaktub dalam Pasal 27 ayat (1) Undang-Undang Dasar Negara Republik Indonesia 1945. Selain itu perlindungan hukum sebagai salah satu aspek penting dalam menjaga integritas Notaris sehingga lembaga Notaris benar-benar menjadi lembaga yang kredibel.

Notaris yang telah berhenti atau diberhentikan dari jabatannya, namun segala hal yang berhubungan dengan akta yang dibuatnya, tentunya masih melekat karena pekerjaan notaris merupakan perbuatan hukum. Oleh karena itu yang perlu dikaji lebih mendalam yaitu bagaimana pertanggungjawaban Notaris terhadap Akta yang dibuat setelah Notaris Werda. Selain itu, apabila terjadi perselisihan ataupun gugatan, tentunya Notaris werda akan menjadi salah satu subjek gugatan. Untuk menjaga kredibilitas lembaga Kenotariatan, maka bagaimana perlindungan hukum terhadap Notaris yang werda dalam hubungannya dengan akta yang dibuatnya. Gugatan yang dilakukan tentunya akan melibatkan pihak lain oleh karena itu bagaimana perlindungan hukum bagi para pihak jika terjadi sengketa atas akta yang dibuat oleh Notaris yang sudah werda sesuai dengan Undang-Undang Nomor 2 Tahun 2014 tentang Perubahan Atas Undang-Undang Nomor 30 Tahun 2004 tentang Jabatan Notaris.

Oleh karena itu, penelitian ini bertujuan untuk mengetahui tanggung jawab Notaris terhadap Akta yang dibuat setelah Notaris werda dan juga untuk mengetahui perlindungan hukum terhadap Notaris yang werda apabila terjadi masalah dengan akta yang buat. Penelitian ini juga bertujuan untuk mengetahui kedudukan hukum protokol notaris setelah berakhirnya jabatan notaris sesuai Undang-undang Nomor 2 Tahun 2014 tentang Perubahan Atas Undang-Undang Nomor 30 Tahun 2004 tentang Jabatan Notaris. 


\section{Rumusa Masalah}

Adapun permasalahan yang diangkat dalam penelitian ini adalah sebagai berikut: Pertama, bagaimana pertanggungjawaban Notaris terhadap akta yang dibuat setelah notaris werda? Kedua, bagaimana perlindungan hukum terhadap Notaris werda dalam hubungannya dengan akta yang dibuatnya? Ketiga, bagaimana perlindungan hukum bagi para pihak jika terjadi sengketa atas akta yang dibuat oleh Notaris werda berdasarkan UUJN?

\section{Tujuan Penelitian}

Berdasarkan rumusan masalah yang telah diuraikan di atas, maka tujuan dari penelitian ini adalah: Pertama, untuk mengetahui tanggungjawab Notaris terhadap Akta yang dibuat setelah werda. Kedua, untuk mengetahui perlindungan hukum terhadap Notaris yang werda apabila terjadi masalah dengan akta yang dibuat. Ketiga, untuk mengetahui kedudukan hukum protocol Notaris setelah berakhirnya jabatan Notaris sesuai dengan UUJN.

\section{Metode Penelitian}

Penelitian ini merupakan jenis penelitian hukum normatif, dimana penelitian normatif empiris bertujuan menelaah kasus berdasarkan undangundang regulasi yang bersangkut paut dengan isu hukum yang sedang ditangani. Spesifikasi penelitian yang digunakan adalah penelitian deskriptif analitis yaitu apa yang dinyatakan responden dan informan secara tertulis atau lisan dan juga perilaku yang nyata yang diteliti dan dipelajari sebagai satu kesatuan yang utuh, tidak semata-mata bertujuan untuk mengungkapkan kebenaran namun juga untuk memahami suatu kebenaran. Sedangkan metode pendekatan yang digunakan dalam penelitian yaitu yuridis normatif dengan metode analisa hukum normatif. Pada penelitian hukum normatif, pengolahan data dilakukan dengan cara mesistematika terhadap bahan-bahan hukum tertulis. Sistematisasi berarati membuat klasifikasi terhadap bahan-bahan hukum tersebut untuk memudahkan pekerjaan analisis dan konstruksi.

\section{Hasil Penelitian dan Pembahasan}

\section{Pertanggungjawaban Notaris terhadap Akta yang Dibuat Setelah Notaris Werda}

Pada hakikatnya Notaris sebagai pejabat, batasan wewenang dan tanggung jawab adalah ketika Notaris masih menjadi pejabat sesuai peraturan perundang-undangan. Oleh karena itu, Notaris dalam membuat Akta harus 
benar-benar sesuai dengan ketentuan yang berlaku agar tidak terjadi masalah ketika Notaris telah werda. Asas kekuatan mengikat tersirat dalam Pasal 1338 ayat (1) KUHPerdata. Setiap perjanjian yang dibuat secara sah berlaku sebagai undang-undang (hukum) bagi mereka yang membuatnya, artinya memiliki daya paksa untuk mematuhi apa yang tertuang di dalam perjanjian. ${ }^{5}$ Oleh karena itu, Notaris harus tetap menjaga prinsip-prinsip tanggung jawab dalam hukum yang meliputi: a. Prinsip tanggungjawab berdasarkan kesalahan (liability based on fault), yaitu prinsip yang menyatakan bahwa seseorang baru dapat dimintakan pertanggungjawabannya secara hukum jika ada unsur kesalahan yang dilakukannya. b. Prinsip praduga untuk selalu bertanggungjawab presumption of liability), yaitu prinsip yang menyatakan tergugat selalu dianggap bertanggungjawab samapai ia dapat membuktikan, bahwa ia tidak bersalah, jadi beban pembuktian ada pada tergugat. c. Prinsip praduga untuk tidak selalu bertanggungjawab (presumption of nonliability), yaitu prinsip ini merupakan kebalikan dari prinsip praduga untuk selalu bertanggungjawab, dimana tergugat selalu dianggap tidak bertanggungjawab sampai dibuktikan, bahwa ia bersalah. d. Prinsip tanggungjawab mutlak (strict liability), dalam prinsip ini menetapkan kesalahan tidak sebagai faktor yang menentukan, namun ada pengecualianpengecualian yang memungkinkan untuk dibebaskan dari tanggungjawab, misalnya keadaan force majeur. e. Prinsip tanggungjawab dengan pembatasan (limitation of liability), dengan adanya prinsip tanggungjawab ini, pelaku usaha tidak boleh secara sepihak menentukan klusula yang merugikan konsumen, termasuk membatasi maksimal tanggungjawabnya. Jika ada pembatasan, maka harus berdasarkan pada perundang-undangan yang berlaku.

Menurut Abdulkadir Muhammad, bahwa dalam teori tanggungjawab dalam perbuatan melanggar hukum (tort liability) dibagi menjadi beberapa teori, diantaranya: ${ }^{6}$ a. Tanggungjawab akibat perbuatan melanggar hukum yang dilakukan dengan sengaja (intertional tort liability), tergugat harus sudah melakukan perbuatan sedemikian rupa sehingga merugikan penggugat atau mengetahui bahwa apa yang dilakukan tergugat akan mengakibatkan kerugian. b. Tanggungjawab akibat perbuatan melanggar hukum yang dilakukan karena kelalaian (negligence tort lilability), didasarkan pada konsep kesalahan (concept of fault) yang berkaitan dengan moral dan hukum yang sudah bercampur baur (interminglend). c. Tanggungjawab mutlak akibat perbuatan melanggar hukum tanpa mempersoalkan kesalahan (stirck liability), hal ini didasarkan pada

${ }^{5}$ Sudaryat, Hukum Bisnis Suatu Pengantar, Ctk. 1, Jendela Mas Pustaka, Bandung, 2008, hlm. 10.

${ }^{6}$ Abdulkadir Muhammad, Hukum Perusahaan Indonesia, Citra Aditya Bakti, Bandung, 2010, hlm. 503. 
perbuatannya baik secara sengaja maupun tidak sengaja, artinya meskipun bukan kesalahannya tetap harus bertanggungjawab atas kerugian yang timbul akibat perbuatannya.

Pemberian sanksi terhadap notaris juga merupakan upaya perlindungan yang diberikan kepada masyarakat, agar terhindar dari tindakan notaris yang merugikan. Sanksi tersebut juga memiliki fungsi untuk menjaga martabat lembaga notaris sebagai lembaga kepercayaan, karena karena kepercayaan masyarakat dapat turun apabila notaris tersebut melakukan pelanggaran, baik pelanggaran yang dilakukan secara sengaja maupun karena kelalaian Notaris.

\section{a. Tanggung Jawab Perdata}

Sanksi keperdataan ialah sanksi yang dijatuhkan terhadap kesalahan yang terjadi akibat wanprestasi maupun perbuatan yang melanggar hukum onrechtmatige daad. Sanksi secara keperdataan dapat berupa penggantian biaya, ganti rugi dan bunga. Notaris akan dimintakan sanksi apabila mendapat gugatan dari para penghadap yang merasa dirugikan akibat akta yang bersangkutan cacat hukum, sehingga mempunyai kekuatan pembuktian sebagai akta dibawah tangan atau batal demi hukum. Akta notaris memiliki kekuatan pembuktian sempurna, namun apabila dilanggar ketentuan tertentu, maka akan terdegradasi nilai pembuktiannya menjadi akta dibawah tangan.

Akta notaris sebagai akta otentik dibuat menurut bentuk dan tata cara yang ditetapkan dalam Pasal 38 s/d Pasal 65 Undang-undang Nomor 2 Tahun 2014 tentang Jabatan Notaris. ${ }^{7}$ Suatu akta menjadi otentik jika memenuhi syarat yang telah ditentukan undang-undang, oleh karena itu seorang notaris dalam melaksanakan tugasnya tersebut wajib : .... melaksanakan dengan penuh disiplin, profesional dan integritas moralnya tidak boleh diragukan. Apa yang tertuang dalam awal dan akhir akta yang menjadi tanggungjawab notaris adalah ungkapan yang mencerminkan keadaan yang sebenar-benarnya pada saat pembuatan akta. ${ }^{8}$

Akta dibawah tangan memiliki nilai pembuktian yang sempurna sepanjang para pihak mengakuinya. Apabila para pihak melanggar ketentuan tertentu seperti yang tercantum dalam UUJN maka akta yang bersangkutan tetap mempunyai kekuatan pembuktian yang sempurna serta mengikat para pihak. Suatu akta yang dinyatakan batal demi hukum, maka akta tersebut dianggap tidak pernah ada atau tidak pernah dibuat, sesuatu yang tidak pernah dibuat tidak dapat dijadikan sebagai dasar suatu tuntutan dalam bentuk kompensasi

\footnotetext{
${ }^{7}$ Ibid., hlm. 16.

8 Tan Thong Kie, Op. Cit., hlm. 166.
} 
kerugian yang biasanya berupa penggantian biaya, ganti rugi dan bunga. Akta notaris yang batal demi hukum tidak dapat dimintakan untuk memberikan penggantian biaya, ganti rugi dan bunga. Hal ini sesuai dengan Pasal 1365 KUHPerdata yang berbunyi "Tiap perbuatan melangar hukum, yang membawa kerugian pada seorang lain, mewajibkan orang yang karena salahnya menerbitkan kerugian itu, mengganti kerugian tersebut. ${ }^{9}$

Penggantian biaya, ganti rugi dan bunga dapat digugat kepada notaris dengan mendasarkan pada hubungan hukum notaris dengan para pihak yang menghdap notaris. Apabila ada pihak yang merasa dirugikan dari akta yang dibuat oleh notaris, maka yang bersangkutan dapat secara langsung mengajukan tuntutan secara perdata terhadap notaris tersebut sehingga notaris tersebut dapat bertanggung jawab secara perdata atas akta yang dibuatnya. Tuntutan penggantian biaya, ganti rugi dan bunga terhadap notaris, tidak didasarkan pada kedudukan alat bukti yang berubah karena melanggar ketentuan-ketentuan tertentu dalam UUJN, tetapi didasarkan kepada hubungan hukum yang terjadi antara notaris dan para pihak yang menghadap notaris tersebut.

\section{b. Tanggung Jawab Administratif}

Selain sanksi keperdataan dan pidana yang dijatuhkan terhadap notaris apabila melakukan pelanggaran, terdapat pula sanksi administrasi. Sanksi administratif bagi notaris yang diatur di dalam UUJN. Sanksi administratif bagi notaris yang tertuang sesuai dengan Pasal 7 ayat (2) Undang-Undang Republik Indonesia Nomor 2 Tahun 2014 tentang Perubahan Atas Undang-Undang Nomor 30 Tahun 2004 tentang Jabatan Notaris sebagai berikut:10 1) Teguran lisan; 2) Teguran tertulis; 3) Pemberhentian sementara; 4) Pemberhentian dengan hormat; 5) Pemberhentian tidak hormat.

\section{c. Tanggung Jawab Pidana}

Tugas pelaksanaan jabatan notaris ialah membuat alat bukti yang dibutuhkan oleh para pihak untuk suatu tindakan hukum tertentu. Notaris membuat akta atas permintaan dari para pihak. Notaris membuat akta berdasarkan alat bukti, keterangan atau pernyataan para pihak yang dinyatakan, diterangkan atau diperlihatkan kepada notaris. Oleh karena itu, dalam pembuatan akta harus disertai dengan dokumen yang legal, dimana apabila notaris memalsukan suatu dokumen, maka akan mendapatkan sanksi pidana.

\footnotetext{
${ }^{9}$ Kitab Undang-Undang Hukum Perdata, Pasal 1365.

${ }^{10}$ Undang-Undang Republik Indonesia Nomor 2 Tahun 2014 tentang Perubahan Atas Undang-Undang Nomor 30 Tahun 2004 tentang Jabatan Notaris, Pasal 7 ayat (2).
} 
Pasal 263: (1) Barangsiapa membuat surat palsu atau memalsukan surat yang dapat menimbulkan suatu hak, perikatan atau pembebasan hutang atau yang diperuntukkan sebagai bukti daripada suatu hal dengan maksut untuk memakai atau menyuruh orang lain memakai surat tersebut dapat menimbulkan kerugian, karena pemalsuan surat, dengan pidana penjara paling lama enam tahun. (2) diancam dengan pidana yang sama, barangsiapa dengan sengaja memakai surat palsu atau yang dipalsukanm seolah-olah sejati jika pemakaian surat tersebut dapat menimbulkan kerugian. ${ }^{11}$ Sedangkan dalam Pasal 416: Seorang pejabat atau orang lain yang diberi tugas menjalankan suatu jabatan umum terus menerus atau untuk sementara waktu, yang sengaja membuat secara palsu atau memlasu buku-buku atau daftar-daftar yang khusus untuk pemeriksaan administrasi, diancam dengan pidana penjara paling lama empat tahun. $^{12}$

\section{Perlindungan Hukum terhadap Notaris Werda atas Akta yang telah Dibuatnya}

Notaris sebagai pejabat publik, dalam menjalankan tugasnya prinsip yang harus dijalankan adalah prinsip kehati-hatian. Namun demikian Notaris manusia biasa tentunya tidak luput dari kelalaian sehingga harus berurusan dengan hukum karena dianggap melanggar peraturan, sehingga perlunya memberikan perlindungan hukum bagi Notaris werda.

Perlindungan hukum merupakan wujud pelayanan yang diberikan oleh negara demi memberikan rasa aman kepada masyarakat. Produk dari suatu jabatan dalam suatu intansi harus sesuai dengan wewenang yang dimiliki oleh jabatan tersebut dan produk tersebut tetap berlaku meskipun pejabat yang bersangkutan sudah tidak menjabat lagi. Apabila ada pihak yang merasa dirugikan dengan adanya produk jabatan yang dibuat oleh pejabat yang berwenang, meskipun pejabat yang bersangkutan sudah tidak menjabat lagi, maka pihak yang merasa dirugikan dapat mengajukan gugatan ke Pengadilan Tata Usaha Negara dan yang digugat ialah obyek dari gugatan tersebut. Hal ini tidak berlaku bagi notaris, produk yang dibuat oleh notaris merupakan akta otentik yang dibuat sesuai kewenangannya yang berdasar pada kehendak para pihak. Sehingga apabila ada pihak yang merasa dirugikan terkait akta yang dibuat oleh notaris, maka pihak tersebut dapat mengajukan gugatan ke Pengadilan Umum. Notaris sebagai pemegang jabatan wajib bertindak professional dalam melaksanakan jabatannya, sesuai dengan standar yang telah

\footnotetext{
${ }^{11}$ Kitab Undang-Undang Hukum Pidana, Pasal 263 ayat (1) dan (2).

12 Ibid., Pasal 416.
} 
ditetapkan dalam UUJN, serta memberikan pelayanan sebaik-baiknya kepada masyarakat.

Muhammad Adama mengemukakan, bahwa dalam PJN dan KUHPerdata umumnya diatur ketentuan tentang pelaksanaan jabatan notaris. Pelayanan jabatan notaris maksudnya adalah untuk membebaskan anggota masyarakat dari penipuan dan kepada orang-orang tertentu memberikan kepastian terhadap hilangnya hak mereka, sehingga untuk kepentingan tersebut diperlukan tindakan preventif yang khusus, antara lain juga mempertahankan kedudukan akta-akta otentik khususnya akta-akta notaris. ${ }^{13}$

Batas waktu pertanggungjawaban notaris adalah sepanjang notaris tersebut menjalankan tugas jabatannya, sampai notaris pensiun karena telah mencapai usia 65 tahun atau diperpanjang hingga 67 tahun, atau pensiun atas permintaan sendiri. Bagi Notaris Pengganti, jika ia tidak lagi bertindak sebagai Notaris Pemegang Protokol Pengganti lagi dan tidak membuat akta lagi, maka Notaris tersebut tidak perlu bertanggung jawab apapun, demikian pula dengan Pejabat Sementara Notaris. Pasal 8 UUJN yang berbunyi: ${ }^{14}$ a. Notaris berhenti atau diberhentikan dari jabatannya dengan hormat karena: 1) meninggal dunia; 2) telah berumur 65 tahun; 3) permintaan sendiri; 4) tidak mampu secara rohani dan/atau jasmani untuk melaksanakan tugas jabatan notaris secara terusmenerus lebih dari 3 tahun; 5) merangkap jabatan sebagaimana dimaksud dalam Pasal 3 huruf g. b. Ketentuan umur sebagaimana dimaksud pada ayat (1) huruf $b$ dapat diperpanjang sampai berumur 67 tahun dengan mempertimbangkan kesehatan yang bersangkutan.

Apabila ada organisasi pelindung notaris ini sebenarnya merupakan filter dari pihak yang berwenang berkaitan dengan penyitaan minuta fotocopy minuta akta, dan filter dari kasus-kasus para pihak yang tidak relevan bagi notaris. Pentingnya perlindungan hukum bagi notaris ialah:15 a. Menjaga keluhuran harkat dan martabat jabatannya, termasuk ketika memberikan kesaksian dan berproses dalam pemeriksaan dan persidangan; b. Merahasiakan keterangan akta guna menjaga kepentingan para pihak yang terkait didalam akta tersebut; c. Menjaga minuta atau surat-surat yang dilekatkan pada minuta akta, serta protokol notaris dalam penyimpanannya.

${ }^{13}$ Muhammad Adam, Asal Usul dan Sejarah Notaris, Sinar Baru, Bandung, 1985, hlm. 45.

${ }^{14}$ Undang-Undang Republik Indonesia Nomor 2 Tahun 2014 tentang Perubahan Atas Undang-Undang Nomor 30 Tahun 2004 tentang Jabatan Notaris, Pasal 8.

15 Suparman Usman, Etika dan Tanggungjawab Profesi Hukum di Indonesia, Gaya Media Pratama, Jakarta, 2008, hlm. 87 
Dengan demikian akan lebih terjamin apabila segala tindakan pemanggilan, pemeriksaan dan penahanan itu dilakukan setelah ada izin dari organisasi profesi yang memeriksanya terlebih dahulu, sehingga pada akhirnya akan tercipta kepastian hukum bagi masyarakat sesuai asas kepercayaan yang mendasari wewenang notaris.

\section{Perlindungan Hukum bagi Para Pihak Jika Terjadi Sengketa atas Akta yang Dibuat oleh Notaris Werda Berdasarkan UUJN}

Dalam proses pembuatan akta di masa lalu, para pihak dapat terlindungi apabila akta yang dibuat telah memenuhi unsur-unsur : unsur kejelasan, unsur kebenaran, unsur kelengkapan dan untuk keabsahan. Unsur kejelasan artinya mulai dari judul akta harus mengandung/mencerminkan secara garis besar substansi dari isi akta, redaksi setiap pasal tidak boleh mempunyai arti lebih dari satu arti/bisa ditafsirkan lain, jangan berpindah ke pasal yang lain sebelum tuntas terkait dengan redaksi pasal tersebut dan memuat secara detail segala sesuatu yang memang harus diatur dalam akta/perjanjian tersebut. Unsur kebenaran artinya sepanjang dimungkinkan mengupayakan kebenaran material. Unsur kelengkapan artinya kelengkapan di sini mengandung pengertian jangan beranjak kepada pasal berikutnya sebelum pasal kelengkapannya benar-benar tuntas. Unsur keabsahan artinya penjelasan tentang keabsahan ini berarti tidak merupakan data yang dipalsukan, dengan cara setiap dokumen- dokumen pendukung sebelum dilakukannya pembuatan akta harus satu persatu di legalisir oleh pejabat yang berwenang agar terjadi kepastian hukum sejak dini sebelum masuk pembuatan akta.

Apabila dikemduian hari terjadi sengketa, dimana salinan akta yang dibawa oleh para pihak hilang atau rusak, maka masih dapat diperolehnya salinan akta dari pemegang protokol Notaris yang werda tersebut. Ketentuan Pasal 65 UUJN tersebut, maka werda notaris tetap bertanggungjawab terhadap akta yang dibuatnya. Oleh karena itu terdapat kerancuan mengenai batas pertanggung jawaban Notaris berdasarkan pada Pasal 65 UUJN yakni meskipun semua akta yang dibuat oleh Notaris telah diserahkan atau dipindahkan kepada pihak penyimpan protokol Notaris, walaupun sudah berhenti atau tidak menjabat lagi sebagai Notaris masih harus bertanggung jawab selama hidupnya.

Pasal 16 ayat (1) huruf d Undang-Undang Nomor 2 Tahun 2014 tentang Perubahan Atas Undang-Undang Nomor 30 Tahun 2004 tentang Jabatan Notaris menyatakan bahwa notaris wajib memberikan pelayanan sesuai dengan ketentuan dalam undang-undang, kecuali bila ada alasan lain untuk menolaknya. Asas ini mengutamakan keahlian (keilmuan) notaris dalam menjalankan tugas jabatannya berdasarkan Undang-Undang Nomor 2 Tahun 2014 tentang 
Perubahan Atas Undang-Undang Nomor 30 Tahun 2004 tentang Jabatan Notaris dan Kode Etik Jabatan Notaris. Tindakan professional notaris dalam menjalankan tugas jabatannya diwujudkan dalam melayani masyarakat dan akta yang dibuat dihadapan atau oleh notaris.

a. Hukum yang melindungi notaris dalam menjalankan tugas jabatannya yaitu ketentuan-ketentuan dalam UUJN, KUHPerdata dan peraturan perundangundangan lainnya. Perlindungan hukum dari regulasi/peraturan perundangundangan yaitu asas lex spesialis derogate legi generali (hukum yang khusus dimenangkan terhadap hukum yang umum) sehingga seharusnya UUJN yang jelas mengatur secara khusus diperuntukkan bagi notaris seharusnya dimenangkan terhadap KUHpidana (yang merupakan hukum yang berlaku umum) tetapi dalam prakteknya tidak demikian.

b. Perlindungan hukum notaris membentengi dirinya sendiri harus mentaati aturan dalam Pasal 15 ayat (2) sampai huruf c dan Pasal 16 ayat (1) huruf a UUJNP. Selain itu notaris harus dalam mebuat akta notaris harus memenuhi beberapa unsur-unsur yaitu:

1) Unsur kejelasan artinya mulai dari judul akta harus mengandung/ mencerminkan secara garis besar substansi dari isi akta, redaksi setiap pasal tidak boleh mempunyai arti lebih dari satu arti/bisa ditafsirkan lain, jangan berpindah ke pasal yang lain sebelum tuntas terkait dengan redaksi pasal tersebut dan memuat secara detail segala sesuatu yang memang harus diatur dalam akta/perjanjian tersebut.

2) Unsur kebenaran artinya sepanjang dimungkinkan mengupayakan kebenaran material. Hal demikian bisa diupayakan dengan pemberian nasehat hukum kepada para penghadap terjkait dengan akta yang akan dibuat dan dikemukkan akibat hukum dan sanksi dalam hal tidak mengemukakan atau menyampaikan segala sesuatu selain daripada yang sebenar-benarnya.

3) Unsur kelengkapan artinya kelengkapan disini mengandung pengertian jangan beranjak kepada pasal berikutnya sebelum pasal kelengkapannya benar-benar tuntas, sehingga dalam membuat akta atau menyusun sebuah akta harus memenuhi syarat kelengkapan dengan dokumen-dokumen, data serta subyek hukum pendukung harus dilengkapi terlebih dahulu sebelum membuat suatu akta dengan tidak boleh mengabaikan satupun data pendukung guna mendapatkan akta yang otentik tersebut.

4) Unsur keabsahan artinya penjelasan tentang keabsahan ini berarti tidak merupakan data yang dipalsukan, dengan cara setiap dokumen- dokumen pendukung sebelum dilakukannya pembuatan akta harus satu persatu di 
legalisir oleh pejabat yang berwenang agar terjadi kepastian hukum sejak dini sebelum masuk pembuatan akta.

c. Ketidakjelasan pengaturan mengenai batas pertanggungjawaban notaris terhadap akta otentik yang dibuatnya dalam Pasal 65 UUJNP akan menimbulkan pemahaman multitafsir sampai kapan beban tanggungjawab tersebut harus dipikul oleh notaris. Berkaitan dengan hal ini terdapat tiga bentuk penafsiran terhadap ketentuan yang terdapat dalam pasal 65 Undangundang Nomor 2 Tahun 2014 tentang Perubahan Atas Undang-Undang Nomor 30 Tahun 2004 tentang Jabatan Notaris.

\section{Penutup}

Berdasarkan hasil dan pembahasan dapat diambil kesimpulan, pertama, tanggung jawab notaris terhadap Akta yang dibuat pada prinsipnya selama notaris masih menjabat maupun sudah wreda. Tanggungjawab notaris terhadap Akta yang dibuat setelah notaris werda ini meliputi perdata, pidana dan administrasi. Kedua, perlindungan hukum terhadap notaris yang telah werda apabila terjadi masalah dengan akta yang buat ialah perlindunganhukum pidana, dimana sesuai dengan yang tertuang pada Pasal 78 ayat (1) angka 3 KUHP yang disebutkan bahwa tuntutan pidana akan hapus setelah 12 tahun terhadap tindak pidana yang diancam hukuman pidana penjara lebih dari 3 tahun. Namun demikian masalah yang harus diperhatikan dalam implementasi perlindungan hukum yaitu bahwa notaris semasa masih menjabat harus memenuhi kewajiban sebagaimana tertuang dalam Pasal 16 ayat (1) UUJN. Ketiga, proses pembuatan akta pada hakekatnnya sudah sesuai ketentuan yang berlaku karena setiap pembuatan akta telah memenuhi unsur kejelasan, unsur kebenaran, unsur kelengkapan dan unsur keabsahan. Pemenuhan unsur-unsur tersebut sebagai bentuk perlindungan hukum preventif pada para pihak.

Adapun saran hasil penelitian ini yaitu: pertama, dalam kondisi apapun juga dan ada tekanan dari pihak manapun juga, notaris harus tetap berpedoman pada peraturan perundang-undangan yang berlaku, agar kelak tidak timbul gugatan; Kedua, notaris perlu lebih berhati-hati terhadap pihak-pihak yang berusaha untuk melanggar prinsip-prinsip dalam pembuatan akta dimana dengan tetap memegang asas proporsional dan asas profesionalitas, maka akan lebih menguntungkan bagi notaris.

\section{Daftar Pustaka}

\section{Buku}

Adam, Muhammad, Asal Usul dan Sejarah Notaris, Sinar Baru, Bandung, 1985. 
Adjie, Habib, Meneropong Khasanah Notaris dan PPAT Indonesia, Citra Aditya Bakti, Bandung, 2009.

, Hukum Notaris Indonesia, Tafsir Tematik Terhadap Undang-Undang Nomor 30 Tahun 2004 tentang Notaris, Refika Aditama, Bandung, 2007. , Kebatalan dan Pembatalan Akta Notaris, Refika Aditama, Bandung, 2011.

Harahap, M. Yahya, Hukum Acara Perdata tentang Gugatan, Persidangan, Penyitaan, Pembuktian dan Putusan Pengadilan, Sinar Grafika, Jakarta.

Kie, Tan Thong, Studi Notariat-Serba Serbi Praktek Notaris, Ichtiar Baru Van Hoeve, Jakarta, 2000.

Muhammad, Abdulkadir, Hukum Perusahaan Indonesia, Citra Aditya Bakti, Bandung, 2010.

Hukum dan Penelitian Hukum, Ctk. 1, Citra Aditya Bakti, Bandung, 2004. , Hukum Perikatan, Citra Aditya Bakti, Bandung, 1992.

Sudaryat, Hukum Bisnis Suatu Pengantar, Ctk. 1, Jendela Mas Pustaka, Bandung, 2008.

Tobing, G.H.S. Lumban, Peraturan Jabatan Notaris, Erlangga, Jakarta, 1983.

, Peraturan Jabatan Notaris (II), Erlangga, Jakarta, 1983. Peraturan Jabatan Notaris (III), Erlangga, Jakarta, 1996.

Usman, Suparman, Etika dan Tanggungjawab Profesi Hukum di Indonesia, Gaya Media Pratama, Jakarta, 2008.

\section{Peraturan Perundang-Undagan}

Kitab Undang-Undang Hukum Perdata (KUHPerdata).

Kitab Undang-Undang Hukum Pidana (KUHPidana).

Undang-Undang Nomor 2 Tahun 2014 tentang Perubahan Atas Undang-Undang Nomor 30 Tahun 2004 tentang Jabatan Notaris. Lembaran Negara Republik Indonesia Tahun 2014 Nomor 2 dan Tambahan Lembaran Negara Republik Indonesia Nomor 5491.

Undang-Undang Nomor 30 Tahun 2004 tentang Jabatan Notaris. Lem baran Negara Republik Indonesia Tahun 2004 Nomor 117 dan Tambahan Lembaran Negara Republik Indonesia Nomor 4432. 